\title{
Comparison of different primer sets for detection of Chlamydia trachomatis by the polymerase chain reaction
}

\author{
R. ROOSENDAAL, J. M. M. WALBOOMERS*, O. R. VELTMAN*, I. MELGERS $\dagger$, C. BURGER†, \\ O. P. BLEKER $\ddagger$, D. M. MACLAREN, C. J. L. M. MEIJER* and A. J. C. VAN DEN BRULE*§
}

Departments of Clinical Microbiology, 'Pathology, and +Gynaecology, Free University Hospital, de Boelelaan 1117. 1081 HV Amsterdam, and $¥$ Department of Gynaecology, Onze Lieve Vrouwe Gasthuis, 1e Oosterparkstraat 179, 1091 HA Amsterdam, The Netherlands

\begin{abstract}
Summary. The sensitivity and specificity of the polymerase chain reaction (PCR) method was studied in vitro with HeLa cells infected with Chlamydia trachomatis serovar L2. Three different primer sets were studied; they were derived from the endogenous plasmid, the nonvariable part of the MOMP gene and the 16S ribosomal RNA (rRNA) gene. The plasmid primers were the most sensitive in the PCR method and detected at least $0 \cdot 1$ infectious unit of C. trachomatis in the presence of a superfluous amount of human DNA. Application of this plasmid PCR to 13 C. trachomatis culture-positive cervical smears containing $<10->200$ inclusion-forming units showed that it was the most sensitive of the three methods and detected $C$. trachomatis in all samples. This correlates with the observation that the plasmid PCR method could detect $C$. trachomatis in cervical smears of four symptomatic patients for up to 3 weeks after the start of treatment with doxycycline. In contrast, the MOMP gene- and rRNA gene-directed PCR, as well as culture and direct immunofluorescence, gave negative results within 1 week. Therefore, we conclude that the plasmid primers are the best candidates for use in the PCR method in $C$. trachomatis screening programmes and clinical follow-up studies.
\end{abstract}

\section{Introduction}

Chlamydia trachomatis is an obligate intracellular gram-negative bacterium. Fifteen different serovars are known and eight of these (D-K) cause urogenital infections, mainly in the western industrialised countries. These infections involve the urethra and cervix and may progress to more serious disorders, such as endometritis, salpingitis and pelvic inflammatory disease, resulting in infertility and ectopic pregnancy. ${ }^{1}$

The current standard technique for diagnosis of $C$. trachomatis infection is isolation of chlamydiae in cell culture. However, the viability of $C$. trachomatis may be compromised by collection, transportation and various steps in the culture procedure which can affect the sensitivity of culture methods. Therefore, several alternative methods have been developed. Antigen detection methods such as direct immunofluorescence (DIF) and enzyme-immunoassays (EIAs) are the most widely used tests that do not rely on growth of $C$. trachomatis.

Recently, DNA hybridisation techniques have been introduced. However, when compared to culture under optimal conditions, these tests were less sen-

Received 23 July 1992; revised version accepted 30 Oct. 1992. $\S$ Correspondence should be sent to Dr A. J. C. van den Brule. sitive. $^{2}$ Furthermore, DIF is a laborious technique that requires great experience, and EIAs may lack specificity, due to the detection of cross-reactive antigens. During recent years, a new sensitive and specific technique for the detection of micro-organisms, the polymerase chain reaction (PCR), has become available. ${ }^{3,4}$ This technique is based on the amplification, potentially by at least a million-fold, of specific nucleotide sequences in a sample, by means of specific primers and Taq DNA polymerase.

PCR methods may overcome the shortcomings of the more conventional techniques for detection of $C$. trachomatis. Several studies have been reported on the use of PCR in C. trachomatis detection. ${ }^{5-17}$ In these studies, primers were used that had been derived from three different $C$. trachomatis-specific DNA sequences-the gene coding for the major outer-membrane protein (MOMP), the 16S ribosomal RNA gene and the $7.5 \mathrm{~kb}$ plasmid. However, in none of these investigations has PCR with primers derived from these three different targets been compared directly. Therefore, we have compared PCR based on primers directed to specific sequences in the MOMP gene, the 16S rRNA gene and the $7 \cdot 5-\mathrm{kb}$ plasmid for their relative sensitivity in detecting serovar L2 DNA from C. trachomatis cultured in HeLa cells. This DNA was isolated from a stock suspension of $C$. trachomatis $\mathrm{L} 2$ titrated in HeLa cells, permitting the sensitivity of each 
PCR to be expressed in terms of inclusion-forming units (ifu). PCR was also performed on cervical smears that were culture-positive in various degrees for $C$. trachomatis. The diagnostic implications of the results of PCR for C. trachomatis, in comparison to those of DIF and culture, were explored by monitoring four symptomatic patients after antibiotic treatment.

\section{Materials and methods}

\section{C. trachomatis strains}

C. trachomatis LGV strains, L2, E and G, were kindly provided by Dr J. H. T. Wagenvoort, Department of Clinical Microbiology, Erasmus University, Rotterdam.

\section{Cervical swabs}

Cervical swabs from women attending the outpatient clinic of the Gemeentelijke Geneeskundige en Gezondheidsdiensten of Amsterdam were kindly provided by $\mathrm{Dr}$ G. J. J. van Doornum. They were placed in $2 \mathrm{ml}$ of sucrose phosphate transport medium (2SP) and used for attempted culture of $C$.trachomatis and for DNA extraction. Samples from four patients with cervicitis-like symptoms (e.g., abnormal discharge) were found to be positive by DIF for $C$. trachomatis at our hospital. These patients and their sexual partners were treated with doxycycline $(100 \mathrm{mg}$ twice daily for 14 days). Endocervical (cytobrush) and urethral (swab) samples were taken and tested by DIF, culture and PCR at $0,1,2,3,4,5$ and 8 weeks after starting the treatment. Smears were prepared on glass slides for DIF and thereafter swab and brush were transferred to 2SP for culture and PCR and then stored at $4^{\circ} \mathrm{C}$.

\section{Direct immunofluorescence}

The cervical smears on glass slides were stained with fluorescent anti-chlamydia monoclonal antibodies (MAbs) (MicroTrak; Syva, USA) according to the manufacturer's instructions.

\section{Culture}

C. trachomatis strain $\mathrm{L} 2$ was grown for 2 days in 80 $\mathrm{cm}^{2}$ flasks containing HeLa 229 cells pre-treated with DEAE dextran $15 \mu \mathrm{g} / \mathrm{ml}$. The chlamydial culture medium consisted of EMEM complete medium (autopow; Flow Laboratories) $\mathrm{pH} 7 \cdot 5$, containing $\mathrm{NaHCO}_{3}$ $0.15 \% \mathrm{w} / \mathrm{v}$, fetal calf serum (Hyclone, USA) $10 \% \mathrm{v} / \mathrm{v}$, vitamins (Flow Laboratories) $1 \% \mathrm{v} / \mathrm{v}$, glutamine (Flow Laboratories) $1 \% \mathrm{v} / \mathrm{v}$, gentamicin $25 \mathrm{mg} / \mathrm{L}$, vancomycin $25 \mathrm{mg} / \mathrm{L}$, amphotericin $B 2.5 \mathrm{mg} / \mathrm{L}$, cycloheximide $0.5 \mathrm{mg} / \mathrm{L}$ and glucose $4.5 \mathrm{~g} / \mathrm{L}$. The monolayer containing the chlamydia inclusions was disrupted by shaking with glass beads. After sonication twice for $15 \mathrm{~s}$ at $7 \mu \mathrm{m}$ amplitude (Soniprep MSE: probe $2.5 \mathrm{~mm}$ ), cell debris was pelleted by centrifugation for $5 \mathrm{~min}$ at $100 \mathrm{~g}$. Chlamydiae were concentrated by centrifugation of the supernate at $30000 \mathrm{~g}$ for $1 \mathrm{~h}$ and then suspended in sucrose phosphate glutamate (SPG) medium.. By titration of 10 -fold dilution series of HeLa cells in microtitration plates, the suspension was found to contain $6.5 \times 10^{5}$ ifu of chlamydia/ml.

Cervical swabs were cultured for $C$. trachomatis on HeLa 229 cells in flat-bottomed tubes (FBT), according to standard procedures, within $24 \mathrm{~h}$ of sample collection. Briefly, HeLa 229 cells were rinsed with $500 \mu \mathrm{l}$ of DEAE-dextran $15 \mu \mathrm{g} / \mathrm{ml}$ in Hanks's Balanced Salts Solution (Oxoid) with $\mathrm{NaHCO}_{3} 0 \cdot 15 \%$ w/v. After the specimens had been agitated, $300 \mu \mathrm{l}$ were added to the HeLa 229 cells. The inoculum was centrifuged on to the cells at $1200 \mathrm{~g}$ for $60 \mathrm{~min}$ and the fluid was replaced by $1 \mathrm{ml}$ of chlamydial culture medium. Samples were incubated for 2 days at $37^{\circ} \mathrm{C}$. The monolayers were fixed with absolute ethanol, stained with fluorescent anti-chlamydia MAbs and examined for fluorescing inclusions. The FBT-culture scores were divided into four groups: $<10,10-100$, 101-200 and $>200$ ifu. The 2SP that remained after taking a sample for culture was stored at $-70^{\circ} \mathrm{C}$.

\section{DNA isolation}

DNA was isolated from $1 \mathrm{ml}$ of the cervical samples in 2SP and from $1 \mathrm{ml}$ of the suspension of strain $\mathrm{L} 2$ (titre $6.5 \times 10^{5} \mathrm{ifu} / \mathrm{ml}$ ). Cells were lysed in SDS $1 \%$ $\mathrm{w} / \mathrm{v}$ and proteinase $\mathrm{K} 150 \mu \mathrm{g} / \mathrm{L}$ by incubation for $30 \mathrm{~min}$ at $37^{\circ} \mathrm{C}$. After phenol extraction, chloroformisoamylalcohol extraction and ethanol precipitation, ${ }^{18}$ the DNA was suspended in $10 \mathrm{~mm}$ Tris, $1 \mathrm{~mm}$ EDTA $\left(\mathrm{T}_{10} \mathrm{E}_{1}\right)$. PCR was performed on $10 \mu \mathrm{l}$ of concentrated isolated DNA of the patient samples, which corresponded to $c .300 \mu \mathrm{l}$ of the original cervical smear suspension in 2SP medium used for culture, on $10 \mu \mathrm{l}$ of serovar L2 DNA, corresponding to $6.5 \times 10^{3}$ ifu in the original serovar L2 suspension, and on $10 \mu \mathrm{l}$ of dilution series of L2 DNA in twice-distilled water. To determine any possible influence of a superfluous amount of DNA on PCR performance chlamydial DNA was diluted in water containing $100 \mathrm{ng}$ of human placental DNA $100 \mathrm{mg} / 10 \mu \mathrm{l}$ and tested by the PCR.

\section{Primers and PCR protocol}

Primer sets derived from three different targets were compared for their sensitivity and specificity in amplifying specific $C$. trachomatis sequences. The following primer sets were used : a plasmid primer set generating a 201-bp fragment, ${ }^{6}$ CtP1 + 5'-TAGTAACTGCCACTTCATCA-3' and CtP2-5'-TTCCCCTTGTAATTCGTTGC-3'; a MOMP gene primer set generating a 129-bp fragment, ${ }^{5} \mathrm{CtM} 1+5^{\prime}$-GCCGCTTTGAGTTCTGCTTCCTC- ${ }^{\prime}$ and CtM2-5'-CCAAGTGGTGCAAGGATCGCA- $3^{\prime}$; and primers derived from the C. psittaci rRNA gene, ${ }^{19}$ CtR $1+5^{\prime}$-GTGGATAG- 
TCTCAACCCTAT- $3^{\prime}$ and CtR2-5'-CCCTAAGTGTTGGCAACTAA-3' generating a band of $310 \mathrm{bp}$. The internal oligonucleotide probes used were: for the plasmid primer set, $\mathrm{pCtP} 1+5^{\prime}$-ATCTCATTACCATGCATTAGCAGCTATCCA-3' ; for the MOMP primer set, pCtM1 + 5'-TCCTTGCAAGCTCTGCCTGTGGGGAATCCT-3'; and for the rRNA primer set, pCtR1 + 5'-GACATGTATTTGACCGCGGCAGAAATGTCG-3'. The three internal oligonucleotide probes, to analyse amplified bands from the different primer sets, were selected by applying a Micro Genie computer program analysis (Beckman, USA). As an internal reaction control in clinical specimens, primers specific for the $\beta$-globin gene were used. ${ }^{3}$ All primers and oligonucleotide probes were synthesised on a Gene Assembler Plus (Pharmacia LKB, Sweden) by the methoxy-phosphoramidite method.

Generally, PCR was performed in $50 \mu \mathrm{l}$ of PCR solution, containing $50 \mathrm{mM} \mathrm{KCl}, 10 \mathrm{~mm}$ Tris- $\mathrm{HCl}$, pH $8 \cdot 3,1.5 \mathrm{mM} \mathrm{MgCl}_{2}, 200 \mu \mathrm{M}$ of each dNTP, $50 \mathrm{pmol}$ of each primer, 1 unit of Taq DNA polymerase (Amplitaq, Cetus, USA) and $10 \mu$ l of DNA sample. The mixture was overlaid with several drops of paraffin oil to prevent evaporation and incubated for $4 \mathrm{~min}$ at $95^{\circ} \mathrm{C}$ for DNA denaturation. Forty cycles of amplification were performed with a PCR processor (Biomed, Germany). Each PCR cycle consisted of a denaturation step at $95^{\circ} \mathrm{C}$ for $1 \mathrm{~min}$, a primer-annealing step at $55^{\circ} \mathrm{C}$ for $2 \mathrm{~min}$ and a chain-elongation step at $72^{\circ} \mathrm{C}$ for $1.5 \mathrm{~min}$. After 40 cycles a temperature-delay step of $4 \mathrm{~min}$ at $72^{\circ} \mathrm{C}$ was done to complete elongation. Ten $\mu \mathrm{l}$ of the amplified PCR products were analysed by agarose $1.5 \% \mathrm{w} / \mathrm{v}$ gel electrophoresis.

\section{Southern blot analysis of PCR products}

DNA was transferred from agarose gel to a Biotrace HP polysulfon-based membrane (Biotrace, Gelman Sciences, USA) by diffusion blotting in $0.4 \mathrm{~N} \mathrm{NaOH}$ overnight. The plasmid, MOMP and rRNA genederived PCR products were analysed for specificity with target-specific internal oligonucleotide probes (see above). Membranes were pre-incubated at $55^{\circ} \mathrm{C}$ in a hybridisation solution $(0.5 \mathrm{~m}$ sodium phosphate, $\mathrm{pH} 7.2, \operatorname{SDS} 7 \% \mathrm{w} / \mathrm{v}$ ) for $2 \mathrm{~h}$. Hybridisation occurred overnight at $55^{\circ} \mathrm{C}$ with $20 \mathrm{pmol}$ of T4 kinase $5^{\prime}\left[\mathrm{y}-{ }^{32} \mathrm{P}\right]$ end-labelled oligonucleotide probes according to standard procedures. ${ }^{18}$ The probes were labelled together in one reaction when hybridised as a cocktail. The filters were washed three times for 15 min with $3 \times \mathrm{SSC}$ (SSC is $0.15 \mathrm{M} \mathrm{NaCl}, 0.015 \mathrm{M}$ sodium citrate) with SDS $0.5 \% \mathrm{w} / \mathrm{v}$ at $55^{\circ} \mathrm{C}$. Autoradiography was performed with Kodak Royal X-omat film and intensifying screens overnight at $-80^{\circ} \mathrm{C}$.

\section{Results}

\section{PCR with C. trachomatis L2 DNA}

Initial experiments were performed on $C$. trachomatis L2 DNA (corresponding to 10 ifu in the PCR) with the three PCR primer sets at annealing temperatures of $45^{\circ}, 50^{\circ}$ and $55^{\circ} \mathrm{C}$, to determine the optimal annealing temperature. The PCR results were not substantially influenced by the annealing temperature within the range tested. In further experiments, an annealing temperature of $55^{\circ} \mathrm{C}$ was used. Relative sensitivity and specificity of PCR with different primer sets were determined by PCR on a 10 -fold dilution series $\left(10^{2}-10^{7}\right)$ of serovar L2 DNA in twice-distilled water.

Fig. 1 shows that the highest sensitivity was reached with the PCR that used primers directed against the endogenous plasmid (lanes 8-14). An equivalent of $0 \cdot 1$ ifu could be detected after ethidium bromide staining in agarose gel (lane 11). Amplification of a part of the MOMP gene (lanes 1-7) and of the 16S rRNA gene (lanes 15-21) was $c$. 10-fold less sensitive. For all three primer sets, the sensitivity of the PCR increased at least 10 -fold after hybridisation, as compared to direct staining of the agarose gel. Human placental DNA (100 $\mathrm{ng}$ in the PCR reaction) affected the sensitivity of the PCR slightly. With the PCR directed against the MOMP gene and the endogenous plasmid, additional PCR products were found (fig. 2a, lanes 1-7 and 8-14). However, these products, did not hybridise with the respective specific probes (fig. $2 b$ ). With the plasmid primers, at least $0 \cdot 1$ ifu was detectable after hybridisation (lane 11).

\section{PCR with culture-positive material}

The relative value of the use of primer sets against different targets for the detection of $C$. trachomatis infection was determined by PCR with DNA isolated from cervical smears of 13 patients that showed various degrees of positivity in culture. All 13 patient samples contained amplifiable DNA as shown by the generation of the 110-bp band amplified from the $\beta$ globin gene. Fig. 3 shows typical PCR results from cervical smears of four patients; the greatest sensitivity was obtained with the plasmid primer set (patients a-d, lane 2). The intensity of PCR signals decreased with decreasing numbers of ifu in the corresponding culture. The overall results obtained for 13 cervical samples are summarised in table I. All 13 samples were positive by plasmid-directed PCR after hybridisation, but only 12 and 10 gave positive results with the MOMP and rRNA genes, respectively, as target. The PCR-negative samples were all weakly positive in culture $(<10$ ifu $)$.

\section{Application of the PCR}

The diagnostic implications of the PCR for detection of C. trachomatis, in comparison with DIF and culture, were investigated by monitoring four $C$. trachomatis-positive patients for several weeks after the start of their treatment with doxycycline. All four patients who were initially DIF-positive were also found to be positive by culture. In three of the four patients, the MOMP gene, plasmid and rDNA PCR 


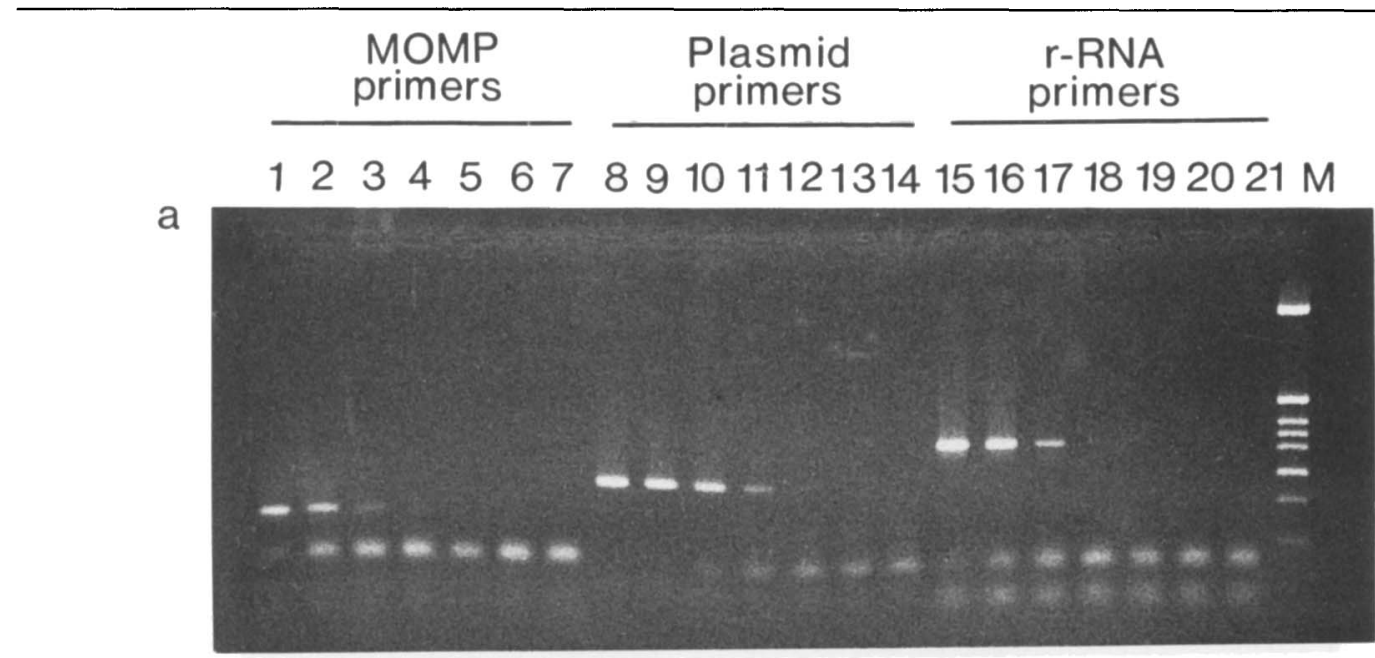

b

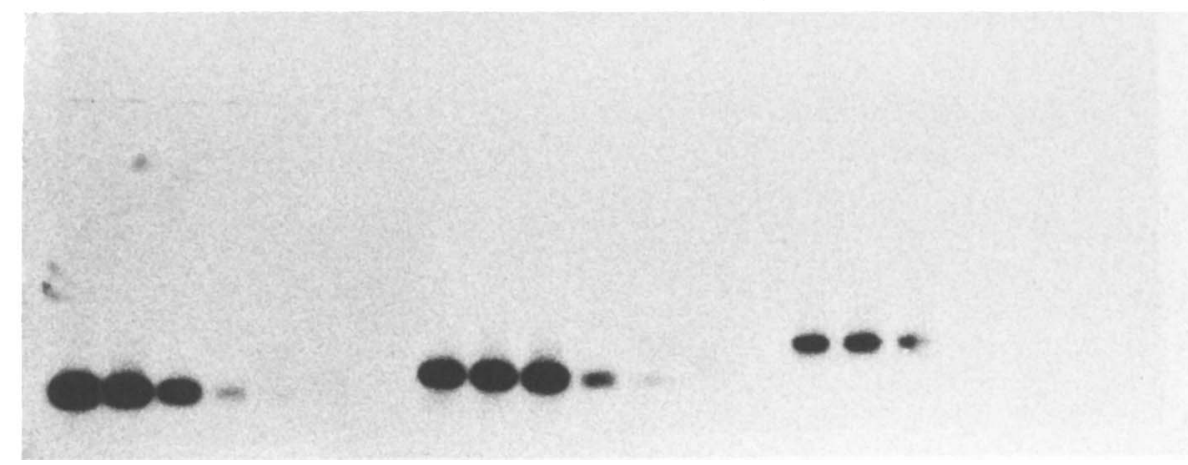

Fig. 1. PCR on a 10-fold dilution series in water $\left(10^{2}-10^{7}\right.$; plus negative control) of $C$. trachomatis $\mathrm{L} 2 \mathrm{DNA}$ with CtM1,2, CtP1,2 and CtR1,2 primers. a, PCR products after electrophoresis on an agarose $1.5 \% \mathrm{w} / \mathrm{v}$ gel and ethidium bromide staining. lanes 1-7, MOMP; 8-14, plasmid; 15-21, rRNA primers; M, pBR322 digested with HinfI. b, Southern blot analysis after hybridisation with target-specific oligonucleotide probes (pCtM1, pCtP1 and pCtR1).

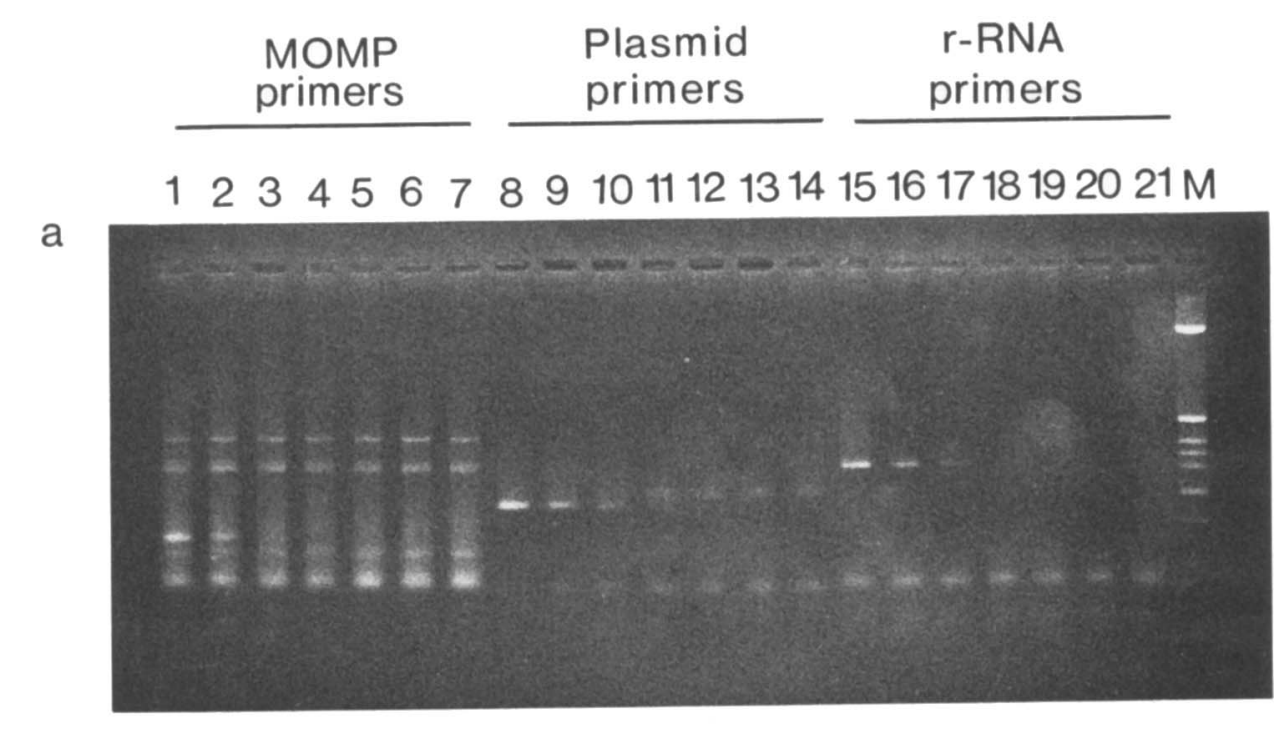

b

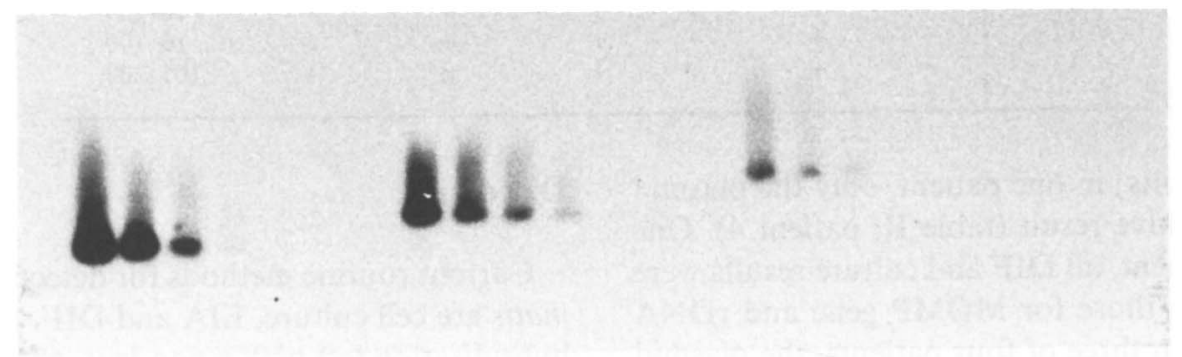

Fig. 2. PCR as in fig. 1, with $100 \mathrm{ng}$ of human placental DNA in the reaction mixture. a, PCR products after electrophoresis on an agarose $1.5 \% \mathrm{w} / \mathrm{v}$ gel and ethidium bromide staining. Lanes 1-7, MOMP; 8-14, plasmid; 15-21, rRNA primers; M, pBR322 digested with Hinfl. b, Southern blot analysis after hybridisation with target-specific oligonucleotide probes (pCtM1, pCtP1 and pCtR1). 


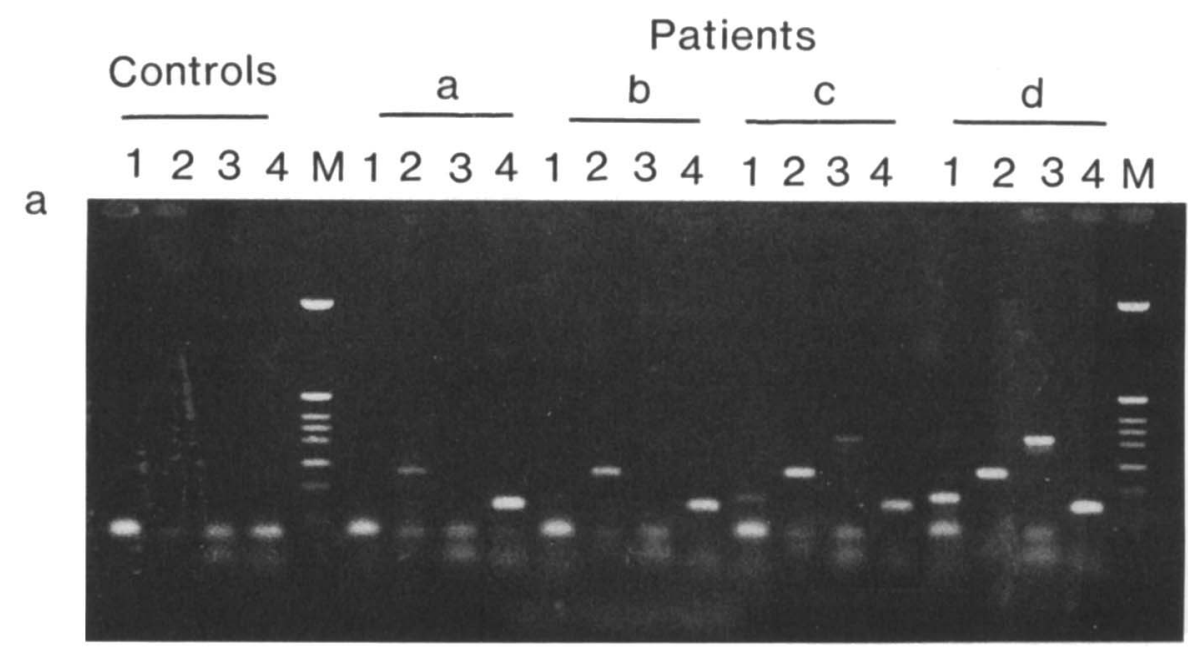

b

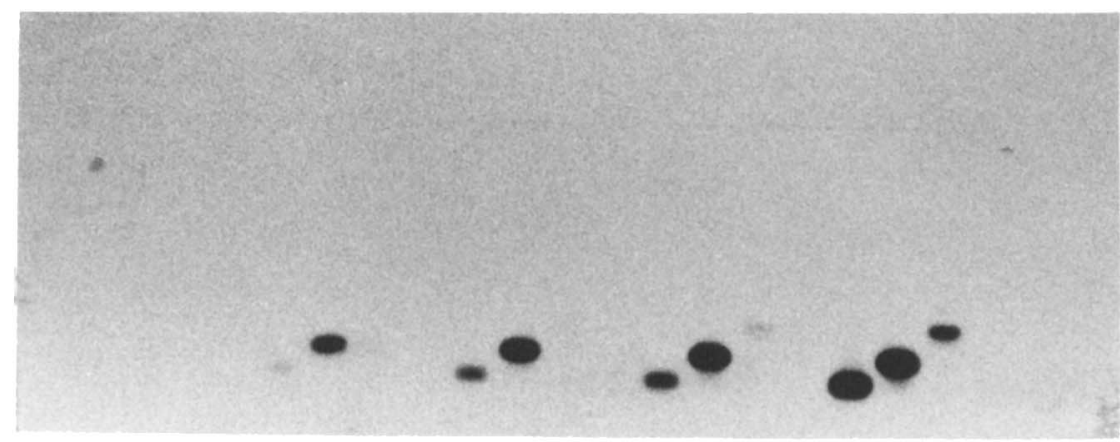

Fig. 3. Detection of $C$. trachomatis in DNA isolated from cervical smears with different numbers of ifu. The positive DNA controls applied in this PCR are shown in fig. 1. a, PCR products after electrophoresis on agarose gel $1.5 \% \mathrm{w} / \mathrm{v}$ and ethidium bromide staining. Lanes 1-4, the negative controls for the MOMP, plasmid, rDNA and $\beta$-globin primers; M, pBR322 digested with HinfI. Patients (a-d) with,+++ +++ and ++++ culture results respectively are shown after PCR with MOMP (1), plasmid (2), rRNA (3) and $\beta$-globin primers (4). b, Southern blot analysis after hybridisation with "cocktail" probe of target-specific oligonucleotides (pCtM1, pCtP1 and pCtR1). Due to photographic reduction, no hybridisation signal is seen with the rRNA primers of patient $b$ (lane 3 ).

Table I. Detection of $C$. trachomatis in 13 culture-positive cervical smears, by PCR with primers directed against the MOMP gene, plasmid and 16S rRNA gene

\begin{tabular}{|c|c|c|c|c|c|c|c|}
\hline \multirow{3}{*}{$\begin{array}{l}\text { Patient } \\
\text { no. }\end{array}$} & \multicolumn{6}{|c|}{ PCR results with } & \multirow{3}{*}{$\begin{array}{l}\text { Numbers of } \\
\text { ifu/sample } \\
\text { by culture }\end{array}$} \\
\hline & \multicolumn{2}{|c|}{$\begin{array}{l}\text { MOMP gene } \\
\text { CtM } 1,2\end{array}$} & \multicolumn{2}{|c|}{$\begin{array}{l}\text { Plasmid } \\
\text { CtPl,2 }\end{array}$} & \multicolumn{2}{|c|}{$\begin{array}{c}\text { 16S rRNA gene } \\
\text { CtR } 1,2\end{array}$} & \\
\hline & Gel & Blot & Gel & Blot & Gel & Blot & \\
\hline 1 & + & + & + & + & + & + & $>200$ \\
\hline 2 & + & + & + & + & + & + & $>200$ \\
\hline 3 & - & + & - & + & - & - & $<10$ \\
\hline 4 & + & + & + & + & + & + & $10-100$ \\
\hline 5 & - & - & - & + & - & - & $<10$ \\
\hline 6 & - & + & - & + & - & - & $<10$ \\
\hline 7 & - & + & + & + & - & + & $<10$ \\
\hline 8 & - & + & + & + & - & + & $<10$ \\
\hline 9 & + & + & + & + & + & + & $>200$ \\
\hline 10 & + & + & + & + & + & + & $<10$ \\
\hline 11 & - & + & + & + & + & + & $10-100$ \\
\hline 12 & - & + & + & + & + & + & $10-100$ \\
\hline 13 & - & + & + & + & - & + & $101-200$ \\
\hline
\end{tabular}

gave positive results; in one patient, only the plasmid PCR gave a positive result (table II, patient 4). One week after treatment, all DIF and culture results were negative, as were those for MOMP gene and rDNA PCR. However, in three of four patients, the plasmid PCR remained positive for $1-3$ weeks after the start of treatment.

\section{Discussion}

Current routine methods for detection of $C$. trachomatis are cell culture, EIA and DIF. More recently, a hybridisation test with a non-isotopic DNA probe has become available commercially. ${ }^{20}$ None of these tests shows optimal sensitivity and only cell culture is $100 \%$ 
Table II. Results for four C. trachomatis-positive patients treated with doxycycline, in a follow-up study

\begin{tabular}{|c|c|c|c|c|c|c|c|c|c|c|c|c|}
\hline \multirow{2}{*}{$\begin{array}{l}\text { Week after } \\
\text { start of } \\
\text { doxycycline } \\
\text { treatment }\end{array}$} & \multicolumn{3}{|c|}{ Patient no. 1} & \multicolumn{3}{|c|}{ Patient no. 2} & \multicolumn{3}{|c|}{ Patient no. 3} & \multicolumn{3}{|c|}{ Patient no. 4} \\
\hline & DIF & Culture & PCR & DIF & Culture & PCR & DIF & Culture & PCR & DIF & Culture & PCR \\
\hline $0^{*}$ & + & + & $+\dagger$ & + & + & $+\dagger$ & + & + & $+\dagger$ & + & + & $+\ddagger$ \\
\hline 1 & - & - & $+\ddagger$ & - & - & - & - & - & $+\ddagger$ & - & - & $+\ddagger$ \\
\hline 2 & ND & ND & ND & - & - & - & - & - & $+\ddagger$ & - & - & - \\
\hline 3 & - & - & $+\ddagger$ & - & - & - & - & - & - & - & - & - \\
\hline 4 & ND & ND & ND & - & - & - & - & - & - & - & - & - \\
\hline 5 & - & - & - & - & - & - & - & - & - & - & - & - \\
\hline 8 & - & - & - & - & - & - & ND & ND & ND & ND & ND & ND \\
\hline
\end{tabular}

ND, not determined.

*Week 0 , samples taken immediately before start of doxycycline treatment.

$\uparrow$ PCR positive for plasmid, MOMP and rRNA target.

†PCR positive only for plasmid target.

specific. $^{2}$ It is hoped that PCR may overcome these shortcomings. Several authors have described a PCR method for the detection of $C$. trachomatis with primers against the MOMP gene,$^{5,9,11,12,15-17}$ the one universally present (with one exception ${ }^{21}$ ) and highly conserved endogenous plasmid ${ }^{6,8,10,13,17}$ and the $16 \mathrm{~S}$ rRNA gene. ${ }^{7,8,14}$ It is clearly important to know whether these three PCR methods differ in sensitivity. Therefore, we compared them for the detection of $C$. trachomatis by performing PCR with primers derived from these three targets, with regard to their sensitivity, and relationship to culture method. Primers were chosen that produce relatively short fragments which are amplified efficiently by PCR performed directly on clinical samples and on pre-treated paraffin-embedded tissues.

The results of PCR with DNA isolated from $C$. trachomatis serovar L2 grown on HeLa cells show that the plasmid PCR was the most sensitive. This can be explained by the presence of multiple copies of the plasmid in each chlamydia cell. Palmer et al.$^{22}$ reported that, in serovar L2, there were 10 plasmid copies/ chromosomal DNA equivalent. The relatively low sensitivity obtained with the $16 \mathrm{~S}$ rDNA primers was unexpected, because other prokaryotic organisms, such as Escherichia coli, have multiple copies of the 16S rRNA gene.$^{23} \mathrm{~A}$ four-fold increase in the primer concentration did not result in an increased sensitivity of the rRNA gene-directed PCR. Therefore, a decrease in sensitivity due to annealing of primers to rRNA is less likely.

With the plasmid primers, an equivalent of about 0.1 ifu was detected in ethidium bromide-stained agarose gels. After hybridisation, a sensitivity of at least 0.01 ifu was reached (fig. 1). An explanation for the higher sensitivity of the PCR compared with culture may be that non-viable chlamydiae are present in the sample, or that chlamydiae which are in their reticulate-body state are detected by PCR and not by tissue culture, because they are not infectious. It is also possible that more than one chlamydia particle is necessary for the formation of one inclusion. Similar results in comparisons of the sensitivity of PCR with the different primer sets and in relation to culture were obtained with serovars $E$ and $G$, two of the eight serovars commonly detected in cervical smears.

Addition of excess human placental DNA (fig. 2) resulted in a slight decrease in the sensitivity of the PCR for all primers, concomitantly with the appearance of additional non-specific amplification products. Mainly, the MOMP primers gave many additional bands; however, the sensitivity obtained with these primers was only slightly decreased. This suggests that, despite the annealing to cellular sequences, the MOMP primer concentration was sufficient to provide a high sensitivity. With the plasmid and rDNA primers, almost no background was found indicating that these primers are highly specific. Under these conditions, the plasmid primers reach a sensitivity of at least $0 \cdot 1$ ifu (fig. 2, lane 11).

Several investigators have determined the sensitivity of the PCR in a model system. When purified elementary bodies (EBs) were used, one copy of target DNA could be detected by both a MOMP genedirected ${ }^{12}$ and plasmid-directed PCR. ${ }^{10}$ However, our data are based on the infectivity of $C$. trachomatis serovar L2 in HeLa cells, and are more closely related to the clinical situation. In terms of ifu, the sensitivity of the PCR applied to each of the different targets is in the same range as that found by other workers. ${ }^{7,11,13}$ When the 16S RNA gene, ${ }^{7}$ MOMP gene, ${ }^{11}$ or plasmidderived primers were used, ${ }^{13}$ sensitivities of $c .0 \cdot 2,0 \cdot 25$, and 0.01 ifu, respectively, were demonstrated.

Other authors have applied PCR to patient samples that were also tested by culture. Claas et al. ${ }^{8}$ found that, in a total of 156 samples, 26 were culture-positive. These 26 samples and two additional ones gave positive results in PCR with both plasmid and rDNA primers. Holland et al. ${ }^{9}$ tested 14 samples, of which two were weakly positive, five strongly positive and seven negative in culture. Forty cycles of PCR on the MOMP target were needed to give visible bands in gels with the weakly positive samples. Bobo et al. ${ }^{11}$ cultured 104 samples and all of 46 that gave positive results were also found to be positive by PCR with MOMP primers. Østergaard et al. ${ }^{10}$ tested 223 clinical 
samples, of which 26 were positive by culture. These and 14 culture-negative samples gave positive results with plasmid-directed PCR. Of the culture-negative samples, $12(86 \%)$ were confirmed as positive by ELISA (IDEIA, Boots-Celltech). All these results suggest that the PCR is at least as sensitive and reliable as culture for detection of $C$. trachomatis. However, none of these authors, except Bobo et al. ${ }^{11}$ report on the number of ifu of $C$. trachomatis in the patient samples. We have shown that when cervical smears are weakly positive by culture for $C$. trachomatis ( $<10$ ifu), the PCR can give negative results, depending on the primers used (table I, patients 3, 5 and 6). Comparison of PCR with the different primer sets on culture-positive cervical smears $(<10->200$ ifu $)$ shows the plasmid primer set to be the most sensitive. After hybridisation, all 13 samples gave positive results with the plasmid primers, in contrast to 12 samples with the MOMP primers and 10 with the rDNA primers. Our results indicate that plasmid primers are the most useful for diagnostic purposes. This is in agreement with the results obtained with the prepared dilution series of $C$. trachomatis strain L2 DNA. The other two primer sets were both $c .10$ times less sensitive in detecting $C$. trachomatis. Our data are in agreement with those obtained by Ossewaarde $e t$ al. ${ }^{17}$ who demonstrated that plasmid-directed PCR was more sensitive than PCR with primers derived from the MOMP gene, both in a model system and when applied to clinical samples. Others found a high sensitivity with MOMP primers. ${ }^{11.15 .16}$ In contrast to our results, Bobo et al. ${ }^{11}$ found all weakly culturepositive $(<10$ ifu $)$ samples to be positive in the PCR test with MOMP primers. However, in both studies the absolute number of ifu obtained is unknown, which may explain the discrepancies observed. Gilroy et $a l^{15}$ demonstrated that $\geqslant 5$ EBs of $C$. trachomatis found by DIF could be confirmed by PCR with MOMP primers. However, when $\leqslant 4 \mathrm{EBs}$ were found, the PCR became negative with some specimens. Nevertheless, this method was applied successfully on synovial samples derived from patients with reactive

\section{References}

1. Schachter J, Dawson CR. Human chlamydial infections. Littleton, MA, PSG Publishing. 1978.

2. Ridgway GL, Taylor-Robinson D. Current problems in microbiology: 1 Chlamydia infections: which laboratory test? $J$ Clin Pathol 1991; 44: 1-5.

3. Saiki RK, Scharf S, Faloona F et al. Enzymatic amplification of $\beta$-globin genomic sequences and restriction site analysis of sickle cell anemia. Science $1985 ; 230$ : $1350-1354$

4. Saiki RK, Gelfland DH, Stoffel S et al. Primer-directed enzymatic amplification of DNA with a thermostable DNA polymerase. Science $1988 ; 239: 487-491$

5. Dutilh B, Bébéar C, Rodriquez $\mathbf{P}$ et al. Specific amplification of a DNA sequence common to all Chlamydia trachomatis serovars using the polymerase chain reaction. Res Microbiol $1989 ; 140$ : 7-16.

6. Griffais R. Thibon M. Detection of Chlamydia trachomatis by the polymerase chain reaction. Res Microbiol 1989; 140: 139-141. arthritis. ${ }^{16}$ Both Bobo et al. ${ }^{11}$ and Gilroy et al. ${ }^{15}$ used only a MOMP gene PCR. Therefore, no conclusions can be drawn about the relative sensitivity of these PCRs, in comparison with that of plasmid PCR.

Our results have also shown that the plasmiddirected PCR can remain positive up to 3 weeks after the start of a 2-week course of treatment with doxycycline, during which period results of culture and DIF, and also PCR with the MOMP gene and 16S rRNA gene primers became negative (table II). This may be due either to a greater sensitivity of the plasmid PCR, or to the presence of some non-viable chlamydial at the sampling sites due to treatment, which are not detected by culture or by the other PCRs. A positive plasmid PCR as a result of re-infection is not likely, because sexual partners of the patients were also treated. It would be interesting to know whether a positive plasmid PCR reflects only the presence of plasmids of dead chlamydiae or the presence of lowcopy numbers of still viable chlamydiae. In the latter case, the patient might still be infectious. This has to be evaluated further. Our results differ from those obtained by Claas et al. ${ }^{24}$ who reported that, with the PCR, 39 samples (including nine urethral samples of men) that were positive at the start of treatment were all PCR-negative within 2 weeks, despite a shorter treatment period of only 1 week. Furthermore, their PCR results were in agreement with those obtained by culture. This discrepancy could be due to a difference in sensitivity between the PCR methods.

In conclusion, our data indicate that PCR directed against the endogenous plasmid is the best candidate for use in the detection of $C$. trachomatis in cervical smears. This conclusion is based on its superior sensitivity in comparison with primers directed against other $C$. trachomatis targets. The plasmid PCR needs to be evaluated further on clinical samples in comparison with current detection techniques such as culture, ELISA or DIF.

This work was supported by the Prevention Fund, The Netherlands grant 28-1182. We thank E. G. A. M. Benneheij (Hogeschool Venlo, The Netherlands) and R. Pol for expert technical assistance.
7. Pollard DR, Tyler SD, Ng C-W, Rozee KR. A polymerase chain reaction (PCR) protocol for the specific detection of Chlamydia spp. Mol Cell Probes 1989; 3: 383-389.

8. Claas HC, Melchers WJ, de Brujn IH et al. Detection of Chlamydia trachomatis in clinical specimens by the polymerase chain reaction. Eur $J$ Clin Microbiol Infect Dis 1990; 9: 864-868.

9. Holland SM, Gaydos CA, Quinn TC. Detection and differentiation of Chlamydia trachomatis, Chlamydia psittaci and Chlamydia pneumoniae by DNA amplification. J Infect Dis 1990 ; 162: 984-987.

10. Østergaard L, Birkelund S, Christansen G. Use of polymerase chain reaction for detection of Chlamydia trachomatis. $J$ Clin Microbiol 1990; 28: 1254-1260.

11. Bobo L, Coutlee F, Yolken RH, Quinn T, Viscidi RP. Diagnosis of Chlamydia trachomatis cervical infection by detection of amplified DNA with an enzyme immunoassay. $J$ Clin Microbiol 1990; 28: 1968-1973.

12. Palmer HM, Gilroy CB, Thomas BJ, Hay PE, Gilchrist C, 
Taylor-Robinson D. Detection of Chlamydia trachomatis by the polymerase chain reaction in swabs and urine from men with non-gonococcal urethritis. J Clin Pathol 1991; 44: $321-325$.

13. Näher $H$, Drzonek $H$, Wolf J, von Knebel Doeberitz $M$, Petzoldt D. Detection of C. trachomatis in urogenital specimens by polymerase chain reaction. Genitourin Med 1991; 67: 211-214.

14. Williams TW, Tyler SD, Giercke S, Pollard DR, McNicol P, Rozee KR. Comparison of polymerase chain reaction and Chlamydiazyme for the detection of Chlamydia trachomatis in clinical specimens. Eur J Clin Microbiol Infect Dis 1992; 11: 233-236.

15. Gilroy CB, Thomas BJ, Taylor-Robinson D. Small numbers of Chlamydia trachomatis elementary bodies on slides detected by the polymerase chain reaction. J Clin Pathol 1992; 45: 531-532.

16. Taylor-Robinson D, Gilroy CB, Thomas BJ, Keat ACS. Detection of Chlamydia trachomatis DNA in joints of reactive arthritis patients by polymerase chain reaction. Lancet 1992; 340: 81-82.

17. Ossewaarde JM, Rieffe M, Rozenberg-Arska M, Ossenkoppele PM, Nawrocki RP, van Loon AM. Development and clinical evaluation of a polymerase chain reaction test for detection of Chlamydia trachomatis. J Clin Microbiol 1992; 30: $2122-2128$.

18. Maniatis T, Fritsch EF, Sambrook J. Molecular cloning, a laboratory manual. New York, Cold Spring Harbor Laboratory. 1982.

19. Weisburg WG, Hatch TP, Woese CR. Eubacterial origin of chlamydiae. $J$ Bacteriol 1986; 167: 570-574

20. Kluytmans JAJW, Niesters HGM, Mouton JW et al. Performance of a nonisotopic DNA probe for detection of Chlamydia trachomatis in urogenital specimens. $J$ Clin Microbiol 1991; 29: 2685-2689.

21. Peterson EM, Markoff BA, Schagter J, De La Maza LM. The $7.5 \mathrm{~kb}$ plasmid present in C. trachomatis is not essential for the growth of this microorganism. Plasmid 1990; 23: 144-148.

22. Palmer L, Falkow S. A common plasmid of Chlamydia trachomatis. Plasmid 1986; 16: 52-62.

23. Lindahl L, Zengel JM. Expression of ribosomal genes in bacteria. Adv Genet 1982; 21: 53-121.

24. Claas HC, Wagenvoort JH, Niesters HG, Tio TT, van RijsoortVos JH, Quint WGV. Diagnostic value of the polymerase chain reaction for chlamydia detection as determined in a follow up study. J Clin Microbiol 1991; 29: 42-45. 